\title{
Comparative analysis of the military pilots training programs in the Romanian Air Force and the Polish Air Force
}

\author{
Eduard Ionut Mihai ${ }^{1, *}$ \\ 1"Henri Coanda" Air Force Academy, Department of Aviation, 160 M. Viteazul, Brasov, Romania
}

\begin{abstract}
The primary purpose of the military pilots training system is to select objectively and to provide practical and qualitative training, both with regard to their academics and in terms of their specialization as aviation personnel. The current state of the military pilots training system has been marked by difficulties due to its attempt in overcoming a prolonged transition period and adapting to modern armed forces and partner training standards within the North Atlantic Treaty Organization. Based on the comparative analysis of the training of military aeronautical personnel in Romania and Poland, we will try to observe whether flight training needs to be more or less phased in order for the Air Force to benefit from pilots capable of responding to the current challenges. Accordingly, the aim of the current paper consists of a qualitative analysis meant to prove the necessity of adjusting curricula to the exigencies of the geopolitical reality within the North Atlantic Treaty Organization and to identify both strong common and distinctive points of the military pilots training programs in the Romanian Air Force and the Polish Air Force.
\end{abstract}

\section{Introduction}

The current aviation military education in the Romanian Air Force is built on one of the world's oldest foundations in the training of pilots, fully reflecting the tradition and experience accumulated over the years. Training programs for pilots, developed by educational institutions under the aegis of the Air Force Staff, "Henri Coanda" Air Force Academy and "Aurel Vlaicu" Air Force Training School are currently marked by a common effort to keep pace with NATO and EU partners' military standards.

The general idea of this article is given by the possibility of provide real feedback on the national education system, and our intention is to add new elements within the qualitative assessment framework concerning the manner in which the training program takes place in our country. The choice of a comparative analysis with the similar program existent in Poland is not at all accidental, the Polish training system being preferred because of similarities with our national training system, and because Polish Air Force has been equipped with F-16 Falcon aircraft, aircraft that are being operationalized and in our country, as well.

\footnotetext{
* Corresponding author: mishued2004@gmail.com
} 
In this article we will analyze the information obtained from the Air Force sources from Romania and Poland, the studies conducted within the structures involved, the data on the efficiency of education and the capitalization of the personal experiences, with the purpose of detailing and evaluating the main aspects of the military aeronautical education systems of the two states.

\section{The educational model specific to the initial training of pilots in the Romanian Air Force}

The training of military pilots, an integral part of the training of officers in the military system, has as its main objectives their acquisition of the general intellectual and military capabilities, as well as their psycho-moral and physical fortification. The planning, organization and conduct of the whole training process of military pilots are based on the principles of education and instruction, following their requirements.

Providing the structures of the Ministry of National Defense with active military pilots is accomplished through four stages: recruitment of candidates, selection and admission of candidates, professional training and professional development [1]. We then considered it useful to focus on each of these stages in order to provide an overview of the training of military pilots in the Romanian Air Force, which will facilitate the achievement of the purpose intended by this article.

In the context of technologically advanced aircraft, within the man-machine relation, it has been shown that the main limitation is the man. Human limitations during flight are much more visible. The pilot must perform his mission with the highest possible success rate to assure the continuity of the action. To this end, in order to identify the best selection criteria and ways of attracting young people inside the Air Force, recruitment and selection methods must be adapted to these new realities.

To be in line with these new challenges, the recruitment and selection process must comply with specific training and development requirements, taking into account a multitude of issues among which we could mention the potential and level of readiness of candidates, the possibility of becoming a successful military leader, good health, psychosocial features characteristic to the military career and, last but not least, excellent physical capabilities.

In this context, the recruitment and selection of candidates is carried out by the specialized structures based on general and specific recruitment criteria, according to the provisions of the "Instructions on Recruitment, Selection, Training and Evolution in the Military Career in the Romanian Armed Forces" [1].

The recruitment of candidates for the training of military pilots in service is achieved by the regional military centers through their recruitment offices, adhering to the general selection criteria set out in the above mentioned instructions and the following specific criteria. Thus, candidates must:

a) be of the maximum age of 24 years old in the year of admission;

b) be graduates of an accredited secondary school with a baccalaureate diploma or to prove the passing of this examination until the date of admission to the training course;

c) not have benefited from university education financed by the state;

d) be declared "Admitted" to the specific aviation personnel's medical tests at the General Aviator "Victor Anastasiu" Institute of Aeronautics and Space Medicine in Bucharest / INMAS.

The first part of the selection takes place at regional recruitment centers and consists of psychological, physical and eliminatory assessment interviews for recruited candidates. Following this stage, the candidate may be in one of the following three situations: 
"admitted", if he has fulfilled the above mentioned requests for evidence; "Rejected" in the case where he did not pass one of the tests; "Not present" when not participating in the recruitment process.

For 'military pilots' specialization, candidates declared "admitted" to the regional recruitment center will have to perform a special medical check at the INMAS for them to be declared "healthy to fly" and then participate further in the selection. From the point of view of medical skills, the medical expertise carried out consists of specific medical tests, in accordance with the type of the aircraft to be flown.

The second phase of the selection, once the above mentioned criteria have been met, is carried out at the educational institutions responsible for the training process. In our case, the admission exam or admission contest is held at "Henri Coanda" Air Force Academy.

The admission to the academy is based on university autonomy and is carried out under the provisions of:

- the Law of National Education no. 1/2011;

- the regulations of the Ministry of National Defense and of the Ministry of Education and Scientific Research;

- the specifications of the General Directorate of Human Resources Management / DGMRU;

- the Methodology of admission to the academy for the next academic year.

According to the "Regulations for organizing and conducting the admission contest for bachelor's and master's programs at "Henri Coanda" Air Force Academy for the academic year of 2019-2020" [2], the admission exam consists of:

"- Stage I: English language - Eliminatory test - 90-minute-multiple-choice test, the minimum score being 6.00 (six).

- Stage II: Mathematics -120-minute-multiple-choice test, which represents $90 \%$ of the admission average, the minimum score in this test being 5.00 (five).

- The average score of the baccalaureate exam represents $10 \%$ in the admission final score.

Candidates declared "admitted" to the specialization 'pilots' will attend the "Aviation Management" study program, thus having access to the training of the flying personnel.

The planning, organization and conduct of the whole training process of military pilots is based on the principles of education and instruction, following their requirements. The professional training of military aeronautical personnel in service starts from the moment of their enrollment in the military system and ends at the moment when they occupy their first military position.

This process of professional training is carried out in specialized institutions and military bases, within the framework of institutionalized training, including military education and individual instruction. Thus, the main structures of the Air Force involved in the training and instruction of military pilots are: the Air Force Staff/ SMFA, the Air Force Academy/ AFA and the Air Force Training School/ SAFA.

During the training, a pilot goes through the following stages in his/her professional development: pilot student - during initial training and pilot in training or aspiring pilot throughout the specialized course required for their employment in their first position.

As we can see, the military pilot training takes place within the AFA, SAFA and other structures authorized by the SMFA, and the structure and training in the Military Pilot Training Program is outlined in Table 1.

Thus, at the AFA, the initial training of the pilot officers in service is provided, at the time of completion and finalization of the undergraduate military studies in accordance with the national standards in the field. This process is based on the educational plans approved by the university senate, in accordance with the requirements of the SMFA or 
other beneficiaries: the Ministry of Administration and Interior, the Naval Forces Staff, etc. These requirements are permanently updated and included in the graduate model.

Table 1. Steps of pilots training

\begin{tabular}{|c|c|c|c|}
\hline STAGE & Period & Structure & Form of training \\
\hline \multirow{6}{*}{$\begin{array}{l}\text { INITIAL } \\
\text { TRAINING }\end{array}$} & \multirow{2}{*}{ First year } & AFA & $\begin{array}{l}\text { - education; } \\
\text { - individual instruction. }\end{array}$ \\
\hline & & $\begin{array}{l}\text { SAFA/ Other } \\
\text { structures }\end{array}$ & - flight instruction. \\
\hline & \multirow{2}{*}{ Second year } & AFA & $\begin{array}{l}\text { - education; } \\
\text { - individual instruction. }\end{array}$ \\
\hline & & $\begin{array}{l}\text { SAFA/ Other } \\
\text { structures }\end{array}$ & - flight instruction. \\
\hline & \multirow{2}{*}{ Third year } & AFA & $\begin{array}{l}\text { - education; } \\
\text { - individual instruction. }\end{array}$ \\
\hline & & $\begin{array}{l}\text { SAFA/Other } \\
\text { structures }\end{array}$ & - flight instruction. \\
\hline $\begin{array}{c}\text { BASIC } \\
\text { COURSE }\end{array}$ & $\begin{array}{c}\text { Fourth year } \\
\text { (possibility of } \\
\text { expansion) }\end{array}$ & $\begin{array}{l}\text { SAFA/Other } \\
\text { structures }\end{array}$ & $\begin{array}{l}\text { - education; } \\
\text { - individual instruction; } \\
\text { - flight instruction. }\end{array}$ \\
\hline
\end{tabular}

The academic education program is conducted over three academic years, and the structure of a university year is divided into two semesters and consists of a minimum of 28 weeks of didactic activities, out of which 6 weeks are allocated to examination sessions and 8 weeks are destined to practical activities [3].

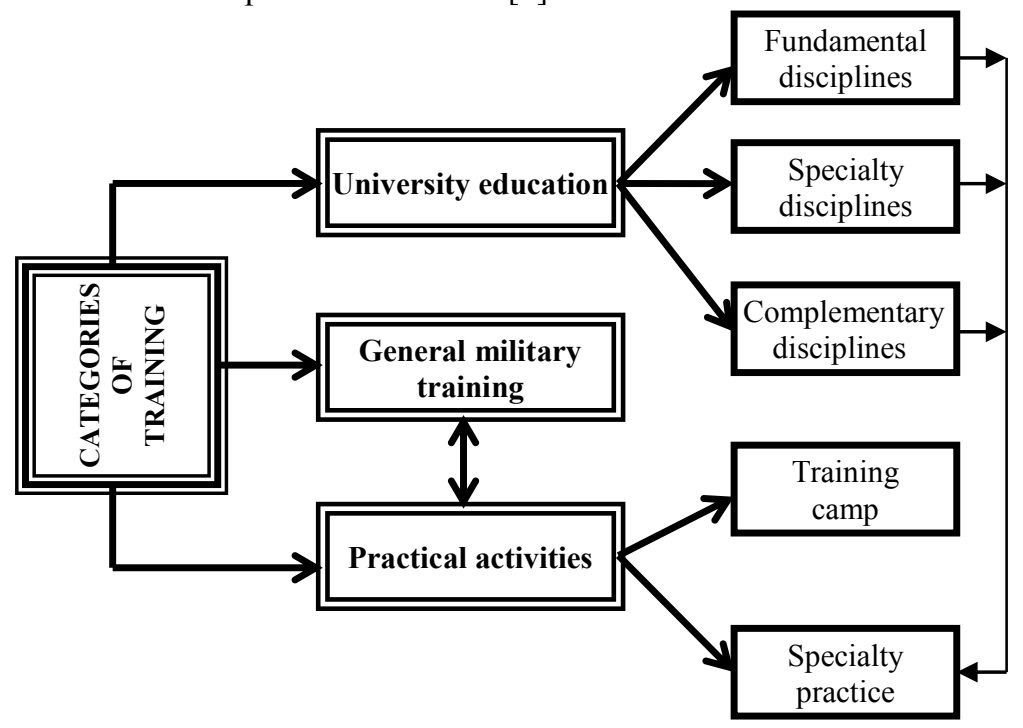

Fig. 1. Training Categories of the Training Process

The formation of military pilots within the AFA is divided into several categories of trainings and we tried to represent its organization by means of Figure 1 [3]. Mention should be made that this structure can be applied to all specializations trained at the Air Force Academy.

The main educational areas for the "Aviation Management" study program are established by the Air Force Staff, based on the professional skills identified by the beneficiaries. In the design of the educational plan, the credits related to each discipline were awarded following the appreciation of the amount of educational effort made by the 
student and the importance of each specific discipline in the training and development of the specialist competences.

The study disciplines were established following the analysis and selection of the content areas, following the specific developmental principles of psycho-pedagogical and scientific types. The time allocated to disciplines within the curriculum is based on an optimal ratio between lectures and applied activities. Each discipline in the curriculum is taught based on the discipline syllabus, in which the objectives and its content, the didactic activities, the form of assessment and the bibliography are stated.

The Military Training Program of the "Henri Coanda" Air Force Academy assures the achievement of the skills and abilities necessary for the graduates to perform their duties related to the weapon for which they are trained, the training to fulfill their assigned battle missions, and to be able to take responsibility for their own training according to subsequent levels of leadership. The Academy forms staff able to understand the internal and international political and military phenomena, the functioning of the rule of law, so that they can constantly find themselves in positions compatible with the military missions, as it is mentioned in the Romanian Constitution.

The practical training sessions provided in the training of the flying personnel are designed to establish the notions learned in the academic training module, to strengthen and develop the students' competences necessary for the use of the aviation technology [4]. The internship course is conducted every year within structures that have agreements with the Air Force (Superior Civil Aviation School) or within the Air Force Training School and are able to carry out initial flight training of pilots. Students under this training program will learn the basic flight skills necessary to them to carry out the flight activity and they will be selected for different categories of aircraft equipping the Romanian Air Force.

The flight training of the Air Force Academy students is on Cessna-172, Piper Seneca V PA-34 and IAK -52 airplanes and Eurocopter EC-120B Colibri and IAR 316-B helicopters. Also, during pilot internships, pilots, except those trained for helicopter specialization, perform parachute jumps to develop their basic skills for possible maneuvers and rescue operations in emergency situations [5].

Upon the completion of their academic years at the AFA, cadets graduate with a degree in "Aviation Management", are promoted to the rank of Second Lieutenants and obtain their flying license. They will mandatorily attend the SAFA basic career course and at the level of the flight training school, the design of the career and refreshment courses is based on the military pilots' training and specialization needs, based on the SMFA graduate model mentioned earlier.

The basic career course for aviation officers lasts for 48 weeks and aims at the theoretical and practical training of trainees to specialize in their weapons and to train for the role of military pilots. Simultaneously with the completion of the SAFA stage, we can say that the process of professional training of military pilots and career development begins.

\section{Aspects regarding training system for military pilots within the Polish Air Force}

In Poland, the training of military pilots is an integral part of the preparation of officers and has as its main objectives the achievement of general intellectual and military capabilities, as well as psycho-moral and physical ones. Thus, as we shall observe from the following, the deployment of the Polish military pilot training process takes place within the Air Force Academy and the 4th Aviation Training Center, and the structure and training of the Military Pilots Training Program in Poland is shown in Table 2 [6]. 
Table 2. Steps of training Polish military pilots

\begin{tabular}{|c|c|c|c|}
\hline STAGE & Period & Structure/Location & Form of training \\
\hline \multirow{5}{*}{$\begin{array}{l}\text { INITIAL } \\
\text { TRAINING }\end{array}$} & \multirow[b]{2}{*}{ First year } & Land Forces Academy / Wroclav & - military training \\
\hline & & Air Force Academy / Deblin & $\begin{array}{c}\text { - education } \\
\text { - individual instruction } \\
\text { - flight instruction }\end{array}$ \\
\hline & $\begin{array}{l}\text { Second } \\
\text { year }\end{array}$ & Air Force Academy / Deblin & $\begin{array}{c}\text { - education } \\
\text { - individual instruction } \\
\text { - flight instruction }\end{array}$ \\
\hline & $\begin{array}{l}\text { Third } \\
\text { year }\end{array}$ & Air Force Academy / Deblin & $\begin{array}{c}\text { - education } \\
\text { - individual instruction } \\
\text { - flight instruction }\end{array}$ \\
\hline & \multirow{2}{*}{$\begin{array}{l}\text { Fourth } \\
\text { year }\end{array}$} & \multirow{2}{*}{$\begin{array}{l}\text { The Air Force Academy and the } 4 \text { th } \\
\text { Training Center / Deblin şi Radom }\end{array}$} & \multirow{2}{*}{$\begin{array}{l}\text { - education } \\
\text { - flight instruction }\end{array}$} \\
\hline \multirow{2}{*}{ SPECIALTY } & & & \\
\hline & $\begin{array}{l}\text { Fifth } \\
\text { year }\end{array}$ & $\begin{array}{l}\text { The Air Force Academy and the 4th } \\
\text { Training Center / Deblin and Radom }\end{array}$ & $\begin{array}{l}\text { - education } \\
\text { - flight instruction }\end{array}$ \\
\hline
\end{tabular}

The academic training of military pilots in Poland starts earlier as compare with other specializations. We can say that a pre-university evaluation stage takes place before the admission examination itself. Thus, once the candidates have completed the steps required for the enrollment (special medical tests and completion of the initial application file), they can participate in a flight training and training phase. This last step is free of charge and usually takes place over five weeks, three for theoretical training and two for flying activities. Due to the costs, the participation of the candidates is limited and is achieved based on their application forms subscribed to the academy, the students of the Polish aviation high school holding priority.

The academic education program is conducted over five academic years, and the structure of a university year is divided into two semesters. After the first seven semesters, when the students complete the courses, a diploma in engineering is obtained, and at the end of the last three semesters, the master's degree is obtained and cadets are promoted to the rank of the second lieutenant [7-8].

The process of training military pilots in the Polish system begins with six weeks of basic military training taking place at the General Tadeusz Kosciuszko Land Forces Academy in Wroclaw. This stage is carried out under the guidance of the Military Land Force instructors, without involving the Air Force Academy personnel and it requires specific infantry training.

The basic military training continues throughout the training cycle both through lectures, and specialized practical sessions held at a rate of twice a year, throughout the five years of study and training on military camps, held annually. As a rule, these military training camps have been allocated two weeks for training and they contribute to the formation of skills and abilities specific to the military system.

The structure and content of the academic training are aligned with the Bologna Convention, relying on providing transferable study credits, as follows: a total of 180 credits for completing the first cycle and a total of 90 credits for the second cycle of Master's program.

Educational standards for aviation specialization are implemented based on technical subjects such as mathematics, physics, mechanics, materials technology, electronics and electro-technology, microprocessor technology, computer science, and automation concepts. In addition to the modules of the basic training, there are the necessary materials 
for training specialists such as aerodynamics, flight mechanics, aircraft construction and operation, air navigation, operational procedures and others highlighted in the curriculum.

For military pilot training, the Polish training system provides graduates with the "BS in aeronautical and aerospace engineering and MS degree in aircraft operations" [7]. Through the field of specialization for military pilots, students aim to acquire the necessary knowledge and skills in safe in-flight exploitation of aircraft, onboard weapon systems, and aviation technical equipment. In this respect, the Polish air force top management have decided that the training of military pilots should be considered technical, a requirement that is also found worldwide.

The training process of Polish military pilots, in addition to the two previously specified military and academic training modules, also includes flight training. This type of training is carried out during the first cycle, annually, at the end of each academic year being allocated, on average, six weeks of training, and in the last years of internships, it grow in intensity and becomes permanent.

At this stage, the gradual training of the pilots, starting with the initial training, continuing with the acquisition of flight licenses on private airplanes or helicopters and commercial airplanes, the instrument flight certificate (PPL (A), PPL (H) and CPL (A) / IR) in accordance with civilian regulations is finalized with the granting of the pilot military license. Practical training of pilots is carried out on "aircraft type DA-20 C, Zlin-143 Lsi, Zlin-242 1, Guimbal Cabri-G2 and Piper PA 34 Seneca" for the training specific to general air traffic and on "PZL-130 Orlik, TS-11 Iskra, SW-4 and Mi-2" type aircraft for the trafficspecific traffic [8].

The promotion to the first military officer rank is not accomplished at the same time with the completion of the postgraduate studies. The graduates have to undertake certain tests and interviews to be assigned their future positions. After the end of this stage, the ceremony of promotion to the military rank is usually held in November of the final year.

\section{Assessing the differences between aeronautical military education systems from Romania and Poland}

The three main areas discussed below will be related to university education, military training and specialist training. The aim is to create an image of the current training of pilots with their strengths or weaknesses.

The medical skill selection process in Poland is similar to the Romanian one, the only significant difference being that future Polish military pilots take the particular test of resistance to gravity acceleration through the centrifuge.

Admission reflects the quality of the raw product to be processed within the training program, and the degree of difficulty in the selection process is directly proportional to the level of the final performance index. Different aspects can be noticed from the initial stage, namely admission to the aviation academies in Romania and in Poland. Thus, in order to become a student at "Henri Coanda" Air Force Academy within the pilot training program, graduates of secondary education have to pass an entrance exam in English and Mathematics examinations, with a medium difficulty level, and in the final admission score, the percentage obtained and the result obtained at the Baccalaureate exam matter. In Poland, there is a need for a more in-depth selection of candidates, with the aim of encompassing the character traits, not only the psycho-physical abilities and intellectual skills, in the candidates' analysis stage. In recent years, it has been demonstrated that the initial pre-test stage, which we have mentioned before, even if it is not mandatory for candidates, has a decisive role in the result of admission.

The way of admission is different from the Romanian one, which consists in the accumulation of a score and the participation in an interview. As a rule, this interview takes 
place after passing the other probes. Thus, the maximum score that can be accumulated by a candidate is 540 and it can be reached by the following criteria [6]:

- a maximum of 300 points can be obtained for the performance of the Matura exam (equivalent to Baccalaureat);

- up to 100 points can be accumulated after the physical test of the admission $(50 \mathrm{~m}$ swimming, traction, $100 \mathrm{~m}$ speed and $1000 \mathrm{~m}$ distance);

- experience in aviation can bring a maximum bonus of 100 points, as follows: To complete the five-week preparation phase mentioned above or to hold a PPL license, you can accumulate 50 points, the glider qualification brings 20 points, 10 jumps with the parachute is awarded 10 points, the paragliding or the glider flyer can bring another 10 points;

- the interview can have a contribution of up to 40 points.

After analyzing the admission process, it is noted that the initial evaluation stage can represent a significant percentage of the final score and, corroborated with the interview, it can influence the admission decisively in the training process of the Polish military pilots. Following the discussions with the Polish Academy instructors, Jaroslaw Kozuba and Adam Bondaruk (both doctors and former military pilots), we concluded that the implementation of this stage is based on two considerations: to determine the degree of motivation of the candidates in the choice made and to optimize the system economically. It is preferable to lower the initial calculated losses to the detriment of some major ones, which may later occur, unpredictably. In opposition, due to the lack of a qualitative assessment and a stage of aptitude testing, admission to the Romanian aeronautical system appears to be more permissive and somewhat deficient when compared to the Polish one.

As far as university education is concerned, the differences exist, as well, and they derive from the structure of the training programs. The Polish training program is oriented towards the technical field, unlike the Romanian one that falls within the socio-human sphere, which disadvantages the Romanian training system.

In the case of the Romanian military aviation education system, minimum performance standards can be achieved with a great deal of ease. The minimum level is 5 on a scale from 1 to 10 . Therefore, for graduation, it is necessary to obtain a minimum of 5 in terms of university education. The Academy of Deblin imposes a system distinct from the Romanian one, the differences being made by the scoring scale and by some minimum limits. The assessment of the knowledge gained in a course is evaluated with scores from 2 to 5 , the minimum performance is represented by grade 2 and the maximum by grade 5 . The values from 3 to 5 obtained in any of the assessments of a course or module allow obtaining credits allocated in the curriculum. In addition to the fact that Polish students must gain a minimum score of 3.50 in a subject, they are required to reach a standard of at least 3.25 points at the end of the third and seventh semesters $[9,10]$.

The aspect of military training is the second point of interest in training pilots to fit the NATO Air Force structures. Military training programs are mandatory, taking into account the specificity of the profession and the environment in which pilosts work. Military training is similar for both programs and it includes theoretical and practical modules, alongside with the modules of academic education, in the structure of the academic year. Leadership is one of the main goals of academies preparing the military personnel that are part of the officers' staff, but different percentages in the efforts of the two educational institutions are directed to the development of command skills. In the preparation of both the Romanian and the Polish one, the military organization of the academies is the essential element requiring the establishment of commanders of various microstructures, but with responsibility and the possibility to exercise the act of limited command. Here we notice a minor advantage of the Polish Academy, which introduced special leadership courses within their curriculum. 
Practical periods of training are designed to establish and implement knowledge gained during theoretical training as well as for the formation and development of basic skills required for the military pilot profession. The structure and schedule of the training courses give the trainees the opportunity to have both theoretical and practical knowledge at the end of their studies, facilitating their specialized and pre-operative training.

Between the two systems, we see a plus on the Polish side that allocates more resources and more time for practical training, an advantage derived from the unitary structure of the military pilots training institution. Probably, if the Romanian Air Force Academy takes over the Civil Aviation School in its structures, the Romanian training system will be closer to the shape of the one in Poland.

We then considered useful the presentation of the essential elements specific to the training processes in tabular form (Table 3) trying to point out suggestively, in our opinion, their strengths.

Table 3. - Criteria specific to the comparison systems

\begin{tabular}{|c|c|c|}
\hline COMPARATIVE CRITERION & ROMANIA & POLAND \\
\hline Length of the training process & 4 years & 5 years \\
\hline The maximum admission age & less than 23 years old & less than 24 years old \\
\hline Medical limitations & Class 1 & Class 1+ centrifuge \\
\hline Interview (character, motivation) & - & Yes \\
\hline Initial Flight Training & - & Permissive condition \\
\hline The condition of being an officer & $\begin{array}{c}\text { At the end of the } \\
\text { process }\end{array}$ & $\begin{array}{c}\text { At the end of the } \\
\text { process }\end{array}$ \\
\hline Simultaneous preparation process & $\begin{array}{c}\text { University, Military } \\
\text { and Specialty }\end{array}$ & $\begin{array}{c}\text { University, Postgraduate, } \\
\text { Military and Specialty }\end{array}$ \\
\hline Performance assessment system & Low rating scale & Average rating scale \\
\hline Leadership & - & $\begin{array}{c}\text { Specialized courses in } \\
\text { the curriculum }\end{array}$ \\
\hline Specialty practice & Throughout the process & Throughout the process \\
\hline Flight experience & $\begin{array}{c}180 \text { hours - GAT } \\
150 \text { hours - OAT }\end{array}$ & $\begin{array}{c}180 \text { hours - GAT } \\
170 \text { hours - OAT }\end{array}$ \\
\hline Graduates trained yearly & 15 & 45 \\
\hline $\begin{array}{c}\text { Estimated costs for the academic } \\
\text { training }\end{array}$ & 32000 Euro & 67000 Euro \\
\hline Budget allocated yearly & 4 mil. Euro & 9 mil. Euro \\
\hline
\end{tabular}

As we can see at first glance, it seems that the training system in Poland is better represented, but to build on this fact and the inherent inefficiencies of the Romanian system, we will analyze the compared criteria punctually as follows:

- With regard to the length of the training process, we find that the Romanian system is disadvantaged, and this fact has logical repercussions in the training of the military pilots which may be more superficial;

- Referring to the selection criteria, we note that we are deficient in the absence of a motivational interview and, in particular, the lack of an initial flight assessment program. We mention that within the medical scales, the overload test found on the Polish is only performed by pilots who will prepare for supersonic aircraft, and in the case of the Romanian pilots this is done on the F-16 airplane without being included in the admissions in the training program;

- For the simultaneity of the training stages, we appreciate that, due to the conditions imposed by the Bologna system, the Polish trainer process is optimal. In the Romanian system the continuation of postgraduate studies is not compulsory [11];

- Regarding the evaluation systems, the differences are minor, but due to the high minimum standard of Poles for the specialized subjects I considered the most appropriate; 
- Analyzing the military training programs, we find that the Romanian process has a significant deficiency caused by the lack of a leadership module. Implementing such a program will result in greater accountability for students and, implicitly, future officers at all levels of training;

- Referring to the specialist training, we appreciate that the Polish system is more appropriate in terms of resource/time balance. It holds the supremacy when we relate to the flight hours not because of their number but for the mode of distribution (an obviously higher proportion of military - OAT type training, to the detriment of civilian GAT);

- The last two criteria relate to costs, and here we can say we are better off relative to the financial effort.

We consider that, following the analysis, the significant deficiencies of the Romanian system consist of the lack of a unitary structure of practical training and in the shorter time allocated to the entire process.

\section{Conclusions}

The organization of education by cycles or levels of study as well as the concept of career guidance includes both common and consistent differences by comparing the two training programs. So, the topic of this article was the qualitative analysis by identifying both common and unique strengths in programs for the training of military pilots in Romania and Poland.

This article represents an attempt to highlight the advantages and disadvantages of the current Romanian training process and to launch the challenges of future research. We want them to materialize in the realization of a draft training program for military pilots at the national level to ensure:

- Optimal selection of the human resource to achieve the objectives of the training process;

- The university training required for specialists who will exploit aircraft of the fourth generation in the near future and, eventually, of the higher generation in the distant future;

- Optimizing flight training for the needs and specificities of the Romanian Air Force, starting from the strengths and minimizing the deficiencies found.

Therefore, the current Air Force pilots training system in our country needs to adapt to prepare future officers to the standards specific to the present and future combat operations.

Even though the approaches are slightly different, the two systems offer the Air force a continuous flux of well-trained military pilots. The stages regarding the Romanian Air Force flying training and its possible methods of making it more effective will be the aim of a further study.

\section{References}

1. Monitorul oficial al României, Partea I, Nr. 229, Instrucţiuni privind recrutarea, selecţia, formarea profesională şi evoluţia în cariera militară în Armata României (2012)

2. Academia Forţelor Aeriene „Henri Coandă” Regulamentului de organizare şi desfăşurare a concursului de admitere pentru programele de licenţă şi master în anul universitar 2019-2020, http:/www.afahc.ro/ro/facultate/documente/Regulamentul\%20de\%20organizare\%20si\%20desfa surarea $\% 20 \mathrm{a} \% 20 \% 20$ concursului $\% 20 \mathrm{de} \% 20$ admitere.pdf, accessed 27.02.2019

3. Academia Forţelor Aeriene „Henri Coandă” Planul de învățământ al AFA valabil începând cu anul universitar 2018-2019, anul I de studii, specializarea Management în aviație (2018)

4. Academia Forţelor Aeriene „Henri Coandă”, Metodologia organizării şi desfăşurării practicii de specialitate de către studenţii academiei, 
http:/www.afahc.ro/ro/facultate/documente/Metodologie $\% 20 \mathrm{de} \% 20$ organizare $\% 20$ si $\% 20$ desfas urare $\% 20 \mathrm{a} \% 20$ practicii $\% 20 \mathrm{de} \% 20$ specialitate.pdf , accessed 15.01 .2019

5. E. I. Mihai, O. Ciuica, Comparative analysis of military flying training systems from Romania and the United States of America, 12 ${ }^{\text {th }}$ Int. Scient. Conf. "Strategies XXI", 3 (2016)

6. Ministry of National Defense of Poland, Concept of education and practical training of the Air Force Academy cadets (2011)

7. M. Adamski, W. Hołyś, Szkoła marzeń-The School of Dreams (Ed. Mariusz Adamski, Warsaw, 2010)

8. D. Bogusz, T. Kulik, Aviation training of candidates for military pilots in the Academic Centre for Aviation Training at the Air Force Academy, Zeszyty Naukowe AON, 3 (96) (2014)

9. Polish Air Force University, Course regulations, https:/www.law.mil.pl/images/kursant/ regulamin kursow/regulamin kursow 2018.pdf accessed 19.01.2019

10. B. Grenda, Training of flying personnel for the needs of the Polish Armed Forces (National Defence University, Warszawa, 2012)

11. E. I. Mihai, Formarea piloților militari-trecut, prezent și viitor (Ed. A.F.A. 2018) 